ЦИВІЛЬНЕ ПРАВО І ЦИВІЛЬНИЙ ПРОЦЕС; СІМЕЙНЕ ПРАВО; МІЖНАРОДНЕ ПРИВАТНЕ ПРАВО

УДК 347.78

DOI https://doi.org/10.32844/2618-1258.2019.6.5

TОКАРЕВА В.O.

\title{
ПОХІДНІ ТВОРИ В ГАЛУЗІ СУЧАСНОГО МИСТЕЦТВА
}

У публікації розглядаються правові аспекти створення похідних творів, право на проведення переробки та використання оригінальних творів у творчості сучасних художників. Встановлено, що наразі культура та суспільство наповнюються готовими зображеннями, захищеними авторським правом за замовчуванням. Огляд художніх творів свідчить, що крім використання однакових сюжетів, ідей, повторення образів своїх попередників, сучасні художники повністю відтворюють зображення фотографій у власних картинах і скульптурах. Така ситуація викликає питання про правову кваліфікацію результатів творчості сучасного мистецтва.

Розглянуто правові наслідки визнання творів сучасного мистецтва в якості похідних творів та визначено, що лише у разі визнання створених творів в якості пародій є вільним (сумлінним) використанням і звільняє переробника від необхідності отримати згоду автора оригіналу на переробку.

Доведено необхідність проведення відмежування між новими, оригінальними творами, які отриманні внаслідок творчого натхнення та $є$ результатом інтелектуальної діяльності, від похідних творів, у яких використаний оригінальний твір, для чого вимагається отримання згоди автора.

Встановлено, що з'ясування питання використання чужого твору без згоди автора (або іншої особи, яка має авторські права), зокрема у формі плагіату чи піратства у сфері авторського права та (або) суміжних прав, судам потрібно призначати проведення судової експертизи у галузі літературознавства та мистецтвознавства.

Встановлено, що при вирішенні питання про можливе використання твору без згоди автора має досліджуватися наявність чинників, які свідчать про незалежний характер творчого результату (наявність виразного образу, нетривіальний підхід, художній образ, схожість творів, техніка вираження індивідуальності та мета художник) з урахуванням того, що авторсько-правова охорона поширюється тільки на форму вираження твору і не поширюється на будь-які ідеї, теорії, принципи, методи, процедури, процеси, системи, способи, концепції.

Ключові слова: авторське право, похідні твори, сумлінне використання, об'єкти авторського права.

This article discusses the legal aspects of creating derivative works, the right to process and use original works in the works of contemporary artists. It is now established that culture and society are now filled with ready-made copyrighted images. A review of works of art shows that, in addition to using the same objects, ideas, and copying predecessors, contemporary artists completely reproduce the images of photographs in their paintings and sculptures. This situation raises the question of the legal qualification of such objects of contemporary art.

The legal consequences of the recognition of works of modern art as derivative works are examined, and if the created works are parodies, this is recognized as free use and frees the processor from obtaining the original author's consent for processing.

To clarify the issue of using someone else's work without the consent of the author (or another person who has copyright), in particular in the form of plagiarism or piracy in the field of copyright and (or) related rights, the courts need to order a forensic exami-

(C) ТОКАРЕВА В.О. - кандидат юридичних наук, доцент кафедри цивільного права (Національний університет «Одеська юридична академія») 
nation and instructions to conduct it in areas of literary criticism, art criticism, depending on the subject of copyright and (or) related rights about what is noted.

While deciding on the possible use of another's work without the consent of the author, the presence of factors that testify to the independent nature of the creative result (the author's contribution to the creation, the presence of expressive image, non-trivial approach, artistic image, similarity of works, artistic technique) should be investigated, given that copyright protection extends only to the form of expression of the work and does not extend to any ideas, theories, principles, methods, procedures, processes, systems, methods, conceptions.

Considerable attention is paid to analysis legal cases of copyright infringement in the field of contemporary art. Methods of analysis and synthesis were used to determine the nature of derivative works and its legal problem of using photographs to create new piece of art without author permission.

Key words: copyright, fair use, derivative art, transformative art, plagiarism, contemporary art, copyright infringement.

Вступ. У цифрову епоху культура та суспільство наповнюються готовими зображеннями, захищеними авторським правом за замовчуванням. Огляд художніх творів свідчить, що крім використання однакових сюжетів, ідей, повторення образів своїх попередників, сучасні художники повністю відтворюють зображення фотографій у власних картинах і скульптурах.

Визнаючи тісний взаємозв'язок мистецтва із запозиченням, апропріацією в умовах інформаційного суспільства, масового оцифрування, доступності результатів інтелектуальної та творчої діяльності в інтернеті, постає питання правової кваліфікації результатів творчості сучасних художників, адже, створюючи провокативний сучасний твір, автор стикається із вірогідністю наразитися не лише на скандал та увагу преси, а й на судовий спір.

Сучасні художники заявляють про свій творчий талант, новизну та власну концепцію радикальними способами. Відомий твір Роберта Раушенберга представляє чистий аркуш паперу, отриманий внаслідок стирання гумкою малюнку Віллема де Кунінга, який художник дав спеціально для цієї мети. Марсель Дюшан прославився використанням готових серійних товарів у власних експозиціях, що стали відомі як "ready made". Джаспер Джонс малював інтерпретації американського прапору та сплавляв у бронзі звичайні предмети як пляшки від пива. Енді Уорхол використовував фотографії зірок із журналів, перетворюючи їх у культові портрети, що неодноразово ставало предметом судових суперечок.

Поширення творів живопису на основі фотографічних творів інших авторів ставить питання критеріїв визнання таких творів незалежними, рівня їх творчого характеру та дотримання вимог отримання згоди автора оригіналу на проведення переробки.

Постановка завдання. Основним завданням $є$ дослідження правових аспектів створення похідних творів, право на проведення переробки та використання оригінальних творів у творчості сучасних художників.

Результати дослідження. Творчі особистості, а з тим і художники в усі часи знаходяться у постійному пошуку та інтерпретують існуючі твори, сюжети та ідеї, тому слід нагадати, що авторсько-правова охорона поширюється на форму вираження, а не на ідеї, процеси, методи функціонування або математичні концепції як такі (відповідно до ст. 2 Договору ВОІВ).

Частиною 3 ст. 3 Закону України «Про авторське право і суміжні права» передбачено, що правова охорона поширюється тільки на форму вираження твору і не поширюється на будь-які ідеї, теорії, принципи, методи, процедури, процеси, системи, способи, концепції, відкриття, навіть якщо вони виражені, описані, пояснені, проілюстровані у творі.

Малюнки, твори живопису, архітектури, скульптури, графіки і літографії; фотографічні твори, до яких прирівнюються твори, виражені способом, аналогічним фотографії; твори прикладного мистецтва є формами вираження творів у галузі літератури, науки і мистецтва відповідно до ст. 2 Бернської конвенції охорони літературних і художніх творів.

У випадку виникнення спору в галузі мистецтва автори подекуди звинувачують своїх колег у створенні похідних творів без згоди автора оригіналу. Розгляд похідних творів передбачає, що правам автора оригінального твору приділяється різна увага. Так, результатом роботи перекладача стане літературний переклад, який хоча і утворює новий твір, що захищається акторським правом, буде випущений під іменем автора оригіналу. 
У наукових дослідженнях дотримання авторського права виявляється у посиланнях на оригінальний твір; в екранізаціях творів авторське право зазвичай дотримується згадкою автора в числі творців нового твору поряд зі сценаристами, композиторами. Однак у силу творчої специфіки інтелектуальної діяльності деякі їі форми творчості створюють колізії в питаннях статусу твору [1].

Відповідно до ст. 2 Бернської конвенції про охорону літературних і художніх творів переклади, адаптації, музичні аранжування та інші переробки літературного або художнього твору охороняються нарівні з оригінальними творами без шкоди правам автора оригінального твору.

Похідним твором згідно зі ст. 1 Закону України «Про авторське право та суміжні права»є твір, який є творчою переробкою іншого існуючого твору без завдання шкоди його охороні (анотація, адаптація, аранжування, обробка фольклору, інша переробка твору) чи його творчим перекладом на іншу мову (до похідних творів не належать аудіовізуальні твори, отримані шляхом дублювання, озвучення, субтитрування українською чи іншими мовами інших аудіовізуальних творів).

Законодавець передбачає у ст. 20 Закону України «Про авторське право та суміжні права» за перекладачами й авторами інших похідних творів авторське право на здійснений ними перекладу, адаптацію, аранжування або іншу переробку за умови дотримання ними прав автора, твір якого зазнав перекладу, адаптації, аранжування або іншої переробки, не виключаючи наступні переклади і переробки тих самих творів.

Загальновизнано, що твір має відповідати вимогам чинного законодавства, таким як оригінальність (твір невідомий суспільству і не повторення вже відомого твору), новизна, творчий характер і бути вираженим в об’єктивній формі (яка може сприйматися іншими та відтворюватися) [2].

За визначенням О.I. Харитонової ознака творчості є обов'язковою для визнання творів об'єктами авторського права 3 поширенням на них правової охорони. Творчий характер дозволяє відокремити твір як об'єкт авторського права від творів, які такими не є [3].

3 огляду на критерій творчості В.Я. Іонас пропонував авторські твори розділяти на незалежні та залежні, визначивши останні як твори літератури, мистецтва чи науки, де автором здійснено запозичення частини або повністю істотного елемента із чужого твору, при цьому 3 виявленням власного мистецтва [4].

На думку А.П. Сергєєва критерієм для визнання похідних або залежних творів охорони є вимога творчої самостійності в порівнянні з оригіналом [5].

Твір є оригінальним, творчим, новим поки в ньому виражається індивідуальний, неповторний підхід, задум та ідеї автора.

Ознаками похідного твору у літературі називається створення його на підставі та за допомогою використання існуючого об'єкта авторського права, творчий характер діяльності переробника [7, с. 6]. Відповідно до ст. 441 ЦК України переробка твору є одним із способів використання твору, а право на переробку носить майновий характер та входить до складу виключних майнових права. Виключне право автора (чи іншої особи, якій належить авторське право) на дозвіл чи заборону використання твору іншими особами дає йому право дозволяти або забороняти здійснювати переклади творів, переробки, адаптації, аранжування та інші подібні зміни творів (відповідно до п.п. 5, 6 ч. 3 ст. 15 Закону України «Про авторське право та суміжні права»).

Надання права на переробку твору має відбуватися на підставі договору або може бути передане у порядку спадкування. 3 аналізу ст. 15 Закону України «Про авторське право та суміжні права» можна дійти висновку, що проведення переробки твору можна здійснити за наявності вираженої згоди автора, яка має бути документально оформлена шляхом укладення ліцензійного договору або договору про відчуження виключних прав.

Творча переробка творів, щодо яких закінчився строк дії авторського права (70 років після смерті автора, крім випадків, передбачених ст. 28 Закону України «Про авторське право та суміжні права») та перейшли у суспільне надбання не вимагає укладення договору, може здійснюватися вільно будь-якою особою, без виплати авторської винагороди за умови дотримання особистих немайнових прав автора (ст. 30 Закону України «Про авторське право та суміжні права»).

Так, у одному з відомих “ready made”, що є листівкою портрету Мона Лізи з домальованими вусами та еспаньйолкою під назвою L.H.O.O.Q. Марсель Дюшан ставить питання про співвідношення мистецтва та естетики. Художником використаний твір Леонардо да Вінчі 1503 року, за часи створення його законодавство про авторське право не існувало.

Аналіз ст. 21 Закону України «Про авторське право та суміжні права» передбачає вичерпний перелік випадків дозволеного або вільного використання творів без згоди автора (чи іншої особи, яка має авторське право) із зазначенням імені автора і джерела запозичення дає підстави 
стверджувати, що створення похідних творів, апропріацій, перекладів, адоптацій, аранжувань вимагає отримання дозволу та не охоплюється випадками вільного використання.

Виключення стосується створення пародій і використання цитат (коротких уривків) з опублікованих творів в обсязі, виправданому поставленою метою, в тому числі цитування статей із газет і журналів у формі оглядів преси, якщо воно зумовлено критичним, полемічним, науковим або інформаційним характером твору, до якого цитати включаються; вільне використання цитат у формі коротких уривків з виступів і творів, включених до фонограми (відеограми) або програми мовлення.

Цитатою за законодавством визначається порівняно короткий уривок із літературного, наукового чи будь-якого іншого опублікованого твору, який використовується 3 обов'язковим посиланням на його автора і джерела цитування іншою особою у своєму творі з метою зробити зрозумілішими свої твердження або для посилання на погляди іншого автора в автентичному формулюванні.

3 огляду на визначення поняття цитати законодавець не обмежує можливість включення цитат не лишу у літературні, наукові, а й у твори візуального мистецтва. У творчості одного 3 найдорожчих художників і скульпторів сучасності Джеффа Кунса можна прослідкувати неодноразові звинувачення у порушенні авторських прав. Так, слід навести справу французького фотографа Жана-Франсуа Бауре проти Джефа Кунса. Художник посилався на те, що скульптура «Оголені» $є$ незалежним твором, будучи пародією на фото. Відповідно до авторського права Франції створення пародій також включається до випадків вільного використання та вимагає можливість відмежувати оригінальний твір від пародії, виявити елемент гумору чи коментарю, що зазвичай $\epsilon$ досить складним і призводить до плутанини. Французький суд визнав, що посилання Джефа Кунса на пародійний характер твору не має ніякої сили та присудив частково відшкодувати збитки, оскільки скульптура була знята з вистави у центрі Помпіду до ії відкриття. Водночас судом не були враховані додані художником квіти у скульптуру, які змінюють вихідний твір.

За визначенням А.П. Сергєєва право на переробку твору включає в себе можливість автору самому переробляти твір в інший вид, форму або жанр або дозволяти переробку іншим особам [5].

Існує позиція, за якою науковці стверджують, що право на переробку та переклад твору має здійснюватися вільно, будучи актом творчості як інші творчі дії, які не можуть регулюватися правовими засобами [7]. Поряд із цим висувається думка, що при вирішенні питання про надання правової охорони похідному твору необхідне дотримання балансу інтересів авторів первинного та похідного твору.

Науковці Е.В. Демьяненко, А.В. Шпак вважають, що отримання дійсно творчих результатів діяльності потребує проведення роботи та $є$ результатом наполегливої праці, тому не погоджуються з позицією розширення кола повноважень вільного використання творів і вільного проведення їх переробки. На думку науковців у першу чергу слід говорити про охорону авторських прав на первинний або оригінальний твір, а виникнення авторських прав на похідний твір виникає у разі дотримання авторських прав на первинний твір. У зв'язку з цим слід розмежовувати випадки переробки творів залежно від дії виключного права. Власне при вирішенні питання переробки твору, строк дії виключного права на який не сплинув, головною умовою для виникнення правової охорони є отримання згоди на використання та переробку твору [8].

На практиці проблеми проведення переробки та створення похідних творів стосується достатності творчого внеску автора та ступеня використання оригінального твору, а в разі виникнення судового спору потребує проведення експертизи фахівцями у відповідній галузі літератури, мистецтва та науки.

Дискусійним серед юристів та мистецтвознавців є питання можливості визнання творів, у яких використані елементи попередніх творів, ремінісценції та алюзії незалежними творами [1]. У разі визнання таких творів похідними творами, апропріацією, адаптацією проведення такої переробки вимагає отримання згоди автора оригінального твору, недотримання якої може призвести до спору з автором.

Якщо старі майстри надихалися міфічними сюжетами, притчами та життям святих, то сучасне мистецтво вихваляє буденність життя, сповнене спрощеннями та запозиченнями. Тому поширеним стає створення творів живопису на основі фотографічних творів інших авторів, що ставить дискусійним питання критеріїв визнання таких творів незалежними або визнання їх похідними та необхідність отримання згоди фотографа на проведення переробки.

У Швеції художник Маркус Андерсон написав картину на основі фотографії із зображенням правопорушника, який був звинувачений у порушенні авторських прав автора фотографії 
Іонаса Лемберга. Перша інстанція під час розгляду справи вирішила, що акцент у картині зроблений на особу порушника, через що картину не можна визнати незалежним твором, а лише похідним твором, апропріацією оригінальної фотографії [9].

Апеляційний суд прийняв протилежне рішення та визнав картину новим незалежним твором, обгрунтовуючи це тим, що зображена на картині особа людини виглядає менш незграбною, ніж на фотографії, а використані фарби більше приглушені та адаптовані до заднього фону, що також зумовлює різницю в тому, як світло падає на обличчя.

За законодавством Швеції адаптація має бути новим оригінальним і незалежним від первісного твором, який використовувався як взірцевий. Якщо нова книга відрізняється власним виразом індивідуальності та оригінальності автора, то такий твір буде розглядатися як нове і незалежне творіння. Остаточне рішення прийняв Верховний суд Швеції, визнавши, що художник трансформував фотографію, створивши новий і незалежний твір, який передає вираження індивідуальності художника [9]. У разі використання автором у власній творчості фотографій колег встановлення ідентичності між фотографією та новим твором подекуди є не настільки очевидним та однозначним.

У справі художника Люка Тюйманса за позовом фотографа Катрейн ван Гіл про порушення авторських прав через портрет, зроблений із фотографії, суд зайняв позицію позивача, визнав художника винним, а картину похідним твором. Картина була майстерно написаним реалістичним портретом чоловіка із відтворенням ракурсу та освітлення, зображеного на фотографії.

На думку Б. Люка, рішення суду Антверпена про визнання винуватим художника Люка Тюйманса у порушенні авторських прав викликає занепокоєння, оскільки судом не була врахована роль апропріації в історії мистецтва та непередбачуваність наслідків прийнятого рішення у майбутньому [10]. Водночас у правовому аспекті створення вочевидь схожого твору потребує отримання згоди автора оригінального твору.

На думку мистецтвознавців, якщо розглядати інтерпретацію позичених зображень, ідей та концепцій із оточуючого світу, використання матеріалів, технік із областей, не пов'язаних із мистецтвом, в якості апропріації або похідних творів призведе до того, що похідними творами буде визнана творчість більшості художників.

У справі Арт Роджерса проти Джеффа Кунса художник був звинувачений за скульптуру «Ряд цуценят» яка повторювала зображення фотографії. Ремісники художника створили роботу відповідно до фотокартки Арт Роджерса і направили їх на створення репродукції зображення. У справі Арт Роджерс проти Джеффа Кунса суд зайняв позицію фотографа, автора визнав винним у порушенні авторських прав.

Суд обгрунтовував рішення тим, що фотографія є досить оригінальною (освітлення, композиції, кут зору), щоб охоронятися авторським правом; Джефф Кунс визнав, що йому була знайома фотокартка та що він дав відповідні вказівки своїм ремісникам скопіювати зображення; визнав намір повторити зображення та істотну подібність між творами. Зображення не підштовхнуло Джеффа Кунса до власної творчості, він не сприйняв ідею Арта Роджерса, а просто незаконно її скопіював [11].

При вирішення питання про можливе використання чужого твору без згоди автора має досліджуватися наявність чинників, які свідчать про незалежний характер творчого результату (наявність виразного образу, нетривіальний підхід, художній образ, схожість творів, техніка вираження індивідуальності, мета художника) з урахуванням того, що авторсько-правова охорона поширюється тільки на форму вираження твору і не поширюється на будь-які ідеї, теорії, принципи, методи, процедури, процеси, системи, способи, концепції.

Висновки. В умовах інформаційного суспільства, оцифрування, доступності результатів інтелектуальної та творчої діяльності у соціальних мережах автори створюють власні об'єкти із використанням творів колег, які охороняються авторським правом, що вимагає отримання згоди на переробку автора оригінального твору.

У випадку виникнення спору, з'ясування питання про можливе використання чужого твору без згоди автора (чи іншої особи, яка має авторське право), зокрема у формі плагіату чи піратства в сфері авторського права і (або) суміжних прав, має вирішуватися за результатами проведення судової експертизи в галузі мистецтвознавства.

\section{Список використаних джерел:}

1. Прояева С.С. Реминисценция: художественный изыск или способ обойти копирайт? / С.С. Прояева, Е.С. Крюкова // Развитие общественных наук российскими студентами. 2017. № 3. C. 112-115. 
2. Токарева В.О. Умови охороноздатності об'єктів авторського права / В.О. Токарева // Приватне та публічне право. 2019. № 3. С. 39-43.

3. Харитонова О.І. Літературні та наукові твори як об'єкти авторських прав / O.I. Харитонова // Часопис иивілістики. 2016. Вип. 21. С. 100-104.

4. Ионас В.Я. Произведения творчества в гражданском праве. М., 1972. с. 56.

5. Сергеев А.П. Право интеллектуальной собственности в РФ. М., 2005. с. 160.

6. Елисеев В.И. Право на переработку произведения по российскому законодательству / В.И. Елисеев // Вестник Московского университета. 2017. № 1 (Серія 11). С. 93-104.

7. Гаврилов Э.П. Право интеллектуальной собственности. Авторское право и смежные права. ХХІ век. М. : Юрсервитум, 2016.

8. Демьяненко Е.В. К вопросу о правовой охране производных произведений / Е.В. Демьяненко, А.В. Шпак // Юристь - Правоведъ. 2019. № 1(88). С. 25-29.

9. Написанная на основе фотографии картина не нарушает авторские права фотографа. URL: https://www.dekuzu.com/ru/2018/04/paintings-based-on-photo-whether-adaptation-orindependent-work.html.

10. Люк Б. Решение суда поперек истории искусства, 16 апреля 2015 год. URL: http://www.theartnewspaper.ru/posts/1542/.

11. Roger vs Koons: A FEUD over a photograph URL: https://www.iprconference.com/blog/ roger-vs-koons-a-feud-over-a-photograph/.

УДК $347.73+342.951$

DOI https://doi.org/10.32844/2618-1258.2019.6.6

ФЕСЕНКО О.М.

\title{
ІНВЕСТИЦІї ТА ІНВЕСТИЦІЙНА ДІЯЛЬНІСТЬ ЯК ОБ'СКТ ПРАВОВОГО ЗАХИСТУ
}

\begin{abstract}
Метою статті є дослідження поглядів на сутність інвестицій та інвестиційної діяльності як об'єкта правового захисту. Так, у статті проаналізовано різні підходи вітчизняних та зарубіжних науковців щодо визначення сутності понять «інвестиції» та «інвестиційна діяльність», визначено суперечні та проблемні моменти в них, здійснено аналіз даних категорій як об'єкта адміністративно-правового захисту. 3'ясовано, що інвестиціями можуть бути: кошти, цільові банківські вклади, паї, акції та інші цінні папери (крім векселів); рухоме та нерухоме майно (будинки, споруди, устаткування та інші матеріальні цінності); майнові права інтелектуальної власності; сукупність технічних, технологічних, комерційних та інших знань, оформлених у вигляді технічної документації, навиків та виробничого досвіду, необхідних для організації того чи іншого виду виробництва, але не запатентованих; права користування землею, водою, ресурсами, будинками, спорудами, обладнанням, а також інші майнові права та інші цінності. Наголошено, що в повсякденній практиці під категорією «інвестиції» розуміється сукупність різних способів капіталовкладення у приватному секторі економіки та використання доходів із метою подальшого збільшення, придбання засобів виробництва. Зроблено висновок, що інвестиційній діяльності держави притаманні основні ознаки фінансової діяльності, що зумовлює можливість ії характеристики як складової частини механізму соціального управління, спрямованого на задоволення публічних інтересів, та свідчить про можливість іiі регулювання нормами фінансового право. У чинному законодавстві відсутні визначення понять «інвестиція» та «інвестиційна діяльність» як об'єктів адміністративно-правового захисту, а отже, повною мірою не
\end{abstract}

публічного права) 